\title{
The Influence of Open Selection and Official Competence in Filling Primary High Leadership Positions on the Organizational Performance of Regional Apparatus in East Belitung Regency
}

\author{
Mudiarsono $^{1}$, Nana Sulaksana ${ }^{2}$, Budi Muljana $^{3}$ \\ ${ }^{1,2,3}$ Universitas Padjajaran Bandung, Indonesia
}

\begin{abstract}
The Merit System and the available options are applied in many Agencies, Institutions and Local Governments to get the best Human Resources. The objectives of this research was to ascertain the impact of open selection and competence on the performance of regional apparatus organizations in the East Belitung Regency. This study employs an explanatory approach with a quantitative approach, analyzing data using descriptive statistics and multiple linear regression. The findings indicated that open selection had a major impact on organizational performance in part. Meanwhile, integrity has a major effect on organizational success on a partial basis. Simultaneous effects of open selection and competence on organizational efficiency are also important.
\end{abstract}

Keywords

open selection; competence; organizational performance

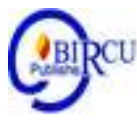

\section{Introduction}

Regional Government Law No 23 of 2014 provides for regions with flexibility in the context of comprehensive regional autonomy. It is responsible for regulating and managing the interests of local communities based on the principles of democracy and justice (Ardianto, 2018). Efforts to support the success of regional autonomy must be supported by qualified State Civil Servants to serve the interests of society professionally, fairly, honestly and correctly (Haris, 2005). State Apparate is the key player in the execution of government functions, production and public services by the government bureaucracy (Ashari, 2010). The Government has enacted the Law Number 5 of 2014 on State Civil Servants as substitute for Act Number 8 of 1974, and Law No 43 of 1999, to provide competent, competence, impartial and high-performing ASNs.

HR has an essential role for Government Organizations because HR is the manager of the system so that the system continues to run; The HR manager must satisfy the requirement of good competence and honesty to provide the community with the best service (Sinambela, 2021). Changes in the times also demand dynamic regulations. Law number 43 of 1999 is deemed unable to meet the needs of the times. The Law does not regulate the principles, principles, fundamental values and code of ethics of Civil Servants (Pattipawae, 2011). To accommodate the needs of the times, Law Number 5 of 2014 concerning the State Civil Apparatus was drafted. There is a fundamental paradigm shift, namely the classification of employees, replaced initially by Civil Servants (PNS) with State Civil Servants (ASN). Types of positions are also regulated in the ASN Law, which is not held in the previous Law, including Administrative Positions, Functional Positions and High Leadership Positions (Pasiak, 2020). Implementation of the merit system in civil service management is the most important reform. ASN law aspires to establish a decentralized, democratic government, free of corruption, collusion and nepotism and capable of good governance. Therefore it is important to develop a state professional 
apparatus, free of corruption, collusion and nepotism without political interference. With high quality and honesty (Meyrina, 2017).

The implementation of the Merid System in ASN Management is the primary mandate in Law Number 5 of 2014. By implementing the Merit System, the appointment, transfer or promotions, remuneration, rewards, and career development of employees are based on employees' qualifications, competencies, and performance. This system creates a sense of justice among employees and can also encourage increased competence and performance. Law number 5 of 2014 brings about fundamental changes in ASN management (Prasojo \& Rudita, 2014). The ASN Law provides the public with great opportunities to take part in the selection process for High Leaders. High leadership positions, as defined under the ASN Law and consisting of main, intermediate and primary senior leadership positions, are high leading positions in government agencies. High Leadership Position is equivalent to Echelon I Officials. Chapter IX of the ASN Law regulates filling out High Leadership Positions. The mechanism controlled for filling the Main, Intermediate and Primary High Leaders is open and competitive among civil servants. Still, in filling certain positions of Main and Intermediate High Leaders, it can be loaded from non-PNS circles with the President's approval (Komara, 2019).

The Government of East Belitung Regency has several times conducted Open Selection in selecting Echelon II officials. For the first time in 2016, and available selection was carried out for filling Middle-Senior Officials (echelon II.a) at the time of the election for the Regional Secretary of East Belitung Regency. In 2017, 2018 and early 2019, another Open Selection was held to fill the Primary High Leaders (echelon II.b) for several Heads of Bodies and Services. In the free selection procedure, the East Belitung Regency Government formed a Selection Committee which involved external parties from academics (Bangka Belitung University and Domestic Government College) as mandated in Government Regulation No.11 of 2017 article 114 paragraph 5 letter c. Before enacting ASN Law No.5 of 2014, the filling of Senior Primary Officials was carried out or deliberated by a team called Baperjakat (Position and Rank Advisory Body) by considering rank, competence, experience, performance etc. Asked for approval, the Regent was inaugurated (Prasojo \& Rudita, 2014).

Based on the above definition, the author is interested in the impact of open selection of high-level positions and official competence on improving the performance of local government organizations in the East Belitung regency.

\section{Review of Literature}

\subsection{Organizational Performance}

An organization is a form of cooperation between a group of people or people in a particular field to achieve a specific goal (Etzioni, 1969). Meanwhile, Menard (2008) states that an organization is a complex human connection formed for a particular purpose, where the relationship between its members is official (impersonal), characterized by collaborative activities, integrated into a broader environment, providing certain services and products and respond to connection with the environment. For every organization, performance appraisal is a significant activity. This assessment can measure the success of an organization within a certain period (Keban, 1995).

There are several defining opinions about organizational performance. Jackson \& Morgan (1978) argued that performance generally shows the level of predetermined goals to be achieved. Rue and Byar in Keban (1995) states that Leisture is known as the degree of results attainment or "the degree of accomplishment" or performance to achieve 
organizational goals on an ongoing basis. Meanwhile, Atmosudirdjo (1997) says that performance can also mean work performance, performance in organizing something. Faustino (2008) defines performance as a way of measuring individual members' contributions to the organization.

According to Peter Jennergen (in Steers, 2003), the notion of organizational performance is the level that shows how far the actual implementation of tasks can be carried out and the organization's mission is achieved. Furthermore (Pamungkas, 2000) explains that performance is how to produce results obtained with activities performed by a performance. Thus, from the concept offered, it can be understood that performance is the central concept of an organization that shows how far the level of ability to carry out organizational tasks to achieve goals. In the context of this research, the meaning of performance is the level of knowledge of each Head of Regional Apparatus Organizations in perform their principal tasks and functions following the vision and mission of the Regional Head.

According to Yani in Syardiansyah (2020) performance is a result of work achieved by a person in carrying out the tasks assigned to him based on skill, experience and sincerity as well as time. However according to Kasmir (2016) that performance is the result of work and work behavior of a person in a period, usually 1 year. Then the performance can be measured by the ability to complete the tasks and responsibilities given. This means that in work contains elements of the standard that achievement must be met, so, for those who reach the standards set means good performance.

Performance management systems are set to aid organizations in order to design and organize what they should do, deliver precise and proper feedforward and feedback on how they are doing. And inspire remedial behavior as and when needed (Anthony \& Govindarajan in Mansaray, 2020)

\subsection{Open Selection}

Open selection often referred to as job tender, is not new from public administration. In the concept of New Public Management (NPM), available selection has been introduced and practiced in Western countries with different terms (Noors, 2019). It aims at selecting equipment that is capable, capable and integrated enough to fill specific roles more effectively and efficiently to carry out their tasks. Open selection is one way of minimizing the potential of corruption, collusion and nepotism $(\mathrm{KKN})$, as jobs are recruited. Transparently, a neutral and knowledgeable party makes the selection by using precise indicators (Nasir, 2019).

The introduction of senior leadership positions is openly reference to Regulation 13 of 2014 on Procedures for Filling High Leadership Openly in Government Agencies of the Government of the Minister of Administrative Reform and Bureaucratic Reform of the Republic of Indonesia:

- Preparation for Open Selection Preparation for available selection is carried out with a Selection Committee by Civil Service Guidance Officers at Regional Agencies in coordination with the State Civil Apparatus Commission (KASN). If the KASN has not been formed, the Regional Personnel Development Officials coordinate with the Minister of Home Affairs and the Minister of Administrative Reform and Bureaucratic Reform.

- Open selection implementation. Procedures for the selection of vacancies, administrative selection and selection results are announced, signed by the Chairman of the Committee of Selection. Selection process is available. Stages of management competence and sector competence selection/ evaluation (task substance). Evaluation of 
management skills is done using the psychometric approach, interviews of expertise, and case review and presentation. In addition, field skills assessment is conducted by written methods and interviews (Field skills requirements are prepared by each organization and assessed according to the needs of the role and can be supported by an evaluator.

Monitoring and Evaluation of Open Selection Candidates selected and appointed (inaugurated) must be given a task orientation by the Personnel Development Officer and the competent official for (one) month. Employment status for candidates who are elected from outside agencies is determined by being employed following the laws and regulations for a maximum of 2 (two) years for performance evaluation. Central and Regional Civil Service Officers submit reports on the implementation of selection for filling high leadership positions openly to KASN and copies of the Minister of Home Affairs and the Minister of Administrative Reform and Bureaucratic Reform.

\subsection{Competence}

Competence is necessary for the successful and productive attainment of company objectives. Highly skilled staff would be able to fulfill their tasks correctly. "Competence is to be able to carry out or execute a job or mission based upon expertise and experience that is matched by the attitude of the job," says Wibowo (2009). Competency is a person's capacity, including an individual's power to pass and implement this expertise and experience in new circumstances and increase the accepted value, to produce satisfactorily at work. Competency also demonstrates the characteristics of the knowledge and skills each person possesses or requires that allow him to effectively carry out his duties and to increase professional quality standards in his work. Wibowo (2009) states that there are five (five) skill forms, namely:

a. A motive is something that people constantly believe or intend to do. The motif leads to a particular activity or purpose and chooses to function.

b. Characteristics and consistent answers to circumstances or facts are characteristics. The response speed and sharpness of the eyes are the physical features of the skill of a fighter pilot.

c. Personality, beliefs or self-image of an individual is a self-concept. Self-confidence is people's conviction that in almost any case they can be successful because of the conception of themselves.

Information an individual has on a particular field is knowledge. Knowledge is a difficult skill. Information testing scores also fail to predict work results, since knowledge and abilities are not measured as they are used on the job. e) Capacity to perform physical or psychological tasks: emotional or cognitive abilities, including analytical and conceptual thought.

\subsection{Research Hypothesis}

$\mathrm{H} 1$ = There is a significant influence between the open selection process variable (X1) partially on the organizational performance variable (Y).

$\mathrm{H} 2$ = There is a significant influence between the employee competency variable (X2) partially on the organizational performance variable (Y).

$\mathrm{H} 3$ = There is a significant influence between the open selection process variable (X1) and competence (X2) simultaneously on employee performance $(\mathrm{Y})$. 


\section{Research Methods}

This research uses explanatory research with a quantitative approach to determine the effect of the open selection process and competence on organizational performance and testing its hypotheses. Singarimbun \& Effendi (2006) explain that if for the same data the researcher explains the causal relationship between variables through hypothesis testing, then the research is no longer called descriptive research but rather hypothesis testing or explanatory research.

Descriptive statistical analysis and several linear regressions were used for data analyses in this research. In describing the study characteristics and the distribution of items per element, descriptive statistical analysis was used. The collected data are then tabulated in a table and descriptively addressed. The hypothesis in this analysis is tested using multiple linear regression. Multiple linear returns are a measuring instrument in this case to decide if the independent variable $(\mathrm{X})$ has an impact on the dependent variable (Y) at the same time (Sugiyono, 2011).

\section{Results and Discussion}

According to the study, each independent variable and its associated variables has a positive and important impact on the dependent variable. This can be summed up as follows.

Table 1. Distribution of Respondents' Answers

\begin{tabular}{|c|l|c|}
\hline No & \multicolumn{1}{|c|}{ Variable } & Mean \\
\hline 1 & Open Selection & 4.12 \\
\hline 2 & Competence & 4,15 \\
\hline 3 & Organizational Performance & 4,13 \\
\hline 4 & Mean Score & 4,13 \\
\hline \multicolumn{2}{|l}{ Source: Processed by researchers }
\end{tabular}

According to the table above, the average score for respondents' responses to each predictor is 4.13. This demonstrates that the process of open selection and expertise in filling primary high-level leadership positions has been beneficial to the organization's success. Additionally, Table 2 below contains partial test results using multiple linear regressions:

Table 2. Partial Test Results

\begin{tabular}{|l|c|c|c|c|}
\hline Independent Variable & Coefficient & $\mathbf{t}$ count & Sig. t & Information \\
\hline Open Selection (X1) & 0.185 & 3.096 & 0.002 & Significant \\
\hline Competence (X2) & 0.163 & 2.088 & 0,042 & Significant \\
\hline Dependent Variable: Organizational Performance (Y) \\
\hline
\end{tabular}

The following equation coefficients were determined based on the results of the multiple linear regression study of the influence of the open selection method (X1) and competence (X2) on organizational success:

$$
Y=7,348+0,185 X 1+0,163 X 2
$$




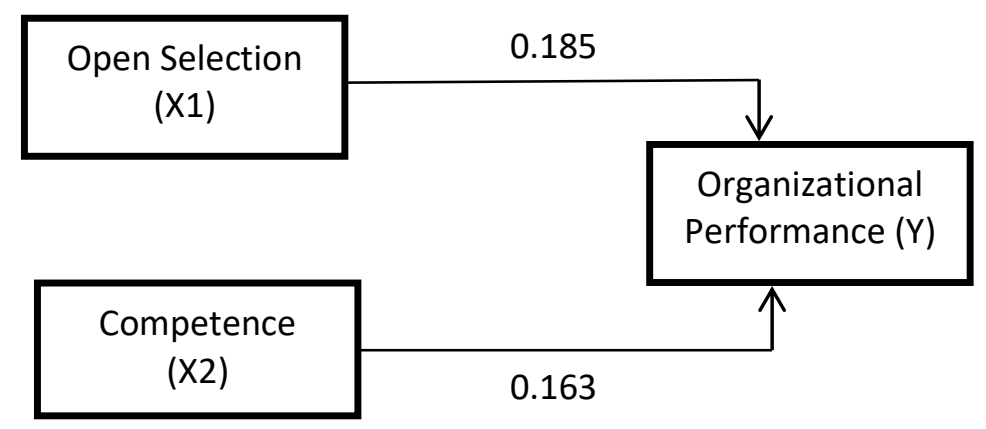

Figure 1. Partial Influence Model

According to the definition above, there is a partial effect between the independent and dependent variables. The open selection method (X1) has a coefficient of 0.185 , while competence (X3) has a coefficient of 0.163. Additionally, Table 3 below illustrates the impact of open selection variables (X1) and competence (X2):

Table 3. Simultaneous Test Results

\begin{tabular}{|l|c|c|c|c|}
\hline \multicolumn{1}{|c|}{$\begin{array}{c}\text { Independent } \\
\text { Variables }\end{array}$} & Dependent Variable & F count & Sig. F & Information \\
\hline $\begin{array}{l}\text { 1. Open Selection (X1) } \\
\text { 2. Competence (X2) }\end{array}$ & $\begin{array}{c}\text { Organizational } \\
\text { Performance (Y) }\end{array}$ & 9.554 & 0.000 & Significant \\
\hline $\begin{array}{l}\text { R-square }=0.414 \\
\text { Adj. R-Square }=0.372\end{array}$ & & & \\
\hline
\end{tabular}

Source: Processed by researchers

According to table 2, the measured F value is 9.554 and the Sig. F value is 0.000 , which indicates that the independent variables of the selection process (X1) and competence (X2) simultaneously affect the dependent variable (organizational performance $(\mathrm{Y})$. The adjusted R-square value obtained is 0.372 , indicating that together the independent variables affect 0.372 or $37.2 \%$ for the dependent variable.

Furthermore, to analyze the results of the hypothesis of the influence of open selection variables and competence in filling high positions on the organizational performance of regional apparatus, the following products are obtained:

1. The effect of the Open Selection Process (X1) on Organizational Performance (Y) partially From the partial calculation results, the open selection process variable (X1) has a positive and significant effect on the organizational performance variable $(\mathrm{Y})$ at an error rate of $0.050(\alpha=5 \%)$ if other variables are assumed to be constant. This can be proven by the coefficient value of 0.185 with a count of 3.096 with a probability of $0.002(0.002<0.050)$, so partially the selection process variable (X1) has a significant effect on the organizational performance variable (Y), meaning that $\mathrm{H} 1$ is accepted.

2. Effect of competence (X2) on organizational performance (Y) partially. From the partial calculation, the competency variable $(\mathrm{X} 3)$ has a positive and significant influence on the organizational performance variable (Y) at an error rate of $0.050(\alpha=5 \%)$ if other variables are assumed to be constant. This can be proven by the coefficient value of 0.163 with a count of 2.088 with a probability of $0.042(0.042<0.050)$, so partially the competency variable (X2) has a significant effect on organizational performance variables (Y), meaning that $\mathrm{H} 2$ is accepted. 
3. The effect of the open selection process (X1) and competence (X2) on organizational performance (Y) Simultaneously From the simultaneous calculation results, the open selection process variables (X1) and competence (X2) have a positive and significant influence on organizational performance variables $(Y)$ at an error rate of $0.050(\alpha=$ $5 \%$ ). This can be proven by the calculated $\mathrm{F}$ value of 9,554 with a probability of 0,000 $(0,000<0.050)$, so simultaneously, the open selection process variables (X1) and competence (X2) have a significant effect on organizational performance variables (Y). The adjusted R-square value is 0.372 , which shows the magnitude of the simultaneous influence of $37.2 \%, \mathrm{H} 3$ is accepted.

According to the results of the multiple linear regression statistical analysis, the open selection process variable has a coefficient of 0.185 and a count value of 3.096 with a probability of 0.002 , indicating that the open selection process variable has a significant effect on organizational performance; this is shown by the significant value being less than (alpha) equal to 0.050. This is reinforced by Aziz et al. (2017)'s observation that selection and placement practices typically concentrate on applicants' expertise, skills, and abilities. Without a good match between employees' experience, expertise, and abilities and work requirements, organizational efficiency will almost certainly suffer, as will other human resource issues.

According to the findings of multiple linear regression analysis, the competency process variable has a coefficient of 0.163 , an at-value of 2.088, and a likelihood of 0.042 , indicating that the recruitment process variable has a major impact on organizational success, as shown by the significance value being less than (alpha) equal to 0.050 . This conclusion is reinforced by Dhamayantie \& Fauzan (2017), who argue that competence has a sizable impact on organizational success. Competence is a fundamental attribute of each person that is correlated with performance parameters that indicate superior or successful performance in a job or situation.

According to the results of the statistical analysis using multiple linear regression, the measured $\mathrm{F}$ value was 9,554, with a significance level of 0.000 . Thus, the available selection variables and expertise have a profound impact on organizational success when used in conjunction (simultaneously). This is founded on a substantial value less than the used alpha of 0.05 . The modified R-square value obtained is 0.372 , indicating that the cumulative impact of the recruiting method (X1), the selection process (X2), and employee competence (X3) on the employee performance variable (Y) is 0.372 , or approximately 37.2 percent, while the remaining 62.8 percent is affected by variables not included in the study, such as employee motivation. This is consistent with Syahril's (2018) assertion that success is a function of motivation and capacity.

\section{Conclusion}

From the results of the research conducted above, it can be concluded that open selection and competence have partial and simultaneous effects on organizational performance. This means that the East Belitung district government must pay attention to the selection process in filling high-ranking positions in the East Belitung district government. By conducting an open selection, it is hoped that more participants will apply and the possibility of getting an official following the needs of a larger organization. Besides, it is necessary to pay attention to selecting officials who will fill high positions. First, the competence must be considered. Good competence will make organizational performance in this case, and the regional apparatus run optimally because officials who have competence will certainly create competent employees. 


\section{References}

Ardianto, S. (2018). Partisipasi Masyarakat Sebagai Solusi Bagi Problematik Implementasi Peraturan Daerah. Jurnal Hukum Khaira Ummah, 13(1), 193-202.

Ashari, E. T. (2010). Reformasi Pengelolaan SDM Aparatur, Prasyarat Tata Kelola Birokrasi Yang Baik. Jurnal Borneo Administrator, 6(2).

Atmosudirdjo, P. (1997). Membangun Visi dan Reorientasi Kinerja Aparatur Daerah, Menjawab Tantangan Masyarakat Indonesia Baru. Manajemen Pembangunan, 19.

Aziz, T. A., Maarif, M. S., \& Sukmawati, A. (2017). Pengaruh Rekrutmen dan Seleksi Terhadap Kinerja. Jurnal Aplikasi Bisnis dan Manajemen (JABM), 3(2), 246-246.

Dhamayantie, E., \& Fauzan, R. (2017). Penguatan Karakteristik dan Kompetensi Kewirausahaan untuk meningkatkan kinerja UMKM. Matrik: Jurnal Manajemen, Strategi Bisnis dan Kewirausahaan.

Etzioni, A. (Ed.). (1969). The Semi-Professions And Their Organization: Teachers, Nurses, Social Workers. Free Press.

Faustino, P. (2008). Restructuring and Turnaround of A Public Service Broadcaster: Public Management with a Private Attitude. Journal of Media Business Studies, 5(3), 53-81.

Haris, S. (Ed.). (2005). Desentralisasi dan Otonomi Daerah: Desentralisasi, Demokratisasi \& Akuntabilitas Pemerintahan Daerah. Yayasan Obor Indonesia.

Jackson, J. H., \& Morgan, C. P. (1978). Organization Theory: A Macro Perspective For Management. Prentice-Hall.

Keban, Y. T. (1995). Indikator Kinerja Pemerintah Daerah. Yogyakarta: UGM.

Komara, E. (2019). Kompetensi Profesional Pegawai ASN (Aparatur Sipil Negara) di Indonesia. Mimbar Pendidikan, 4(1), 73-84.

Mansaray, H. (2020). Organizational Strategies and Performance in the Banking Industry Focused on the Transnational Banks in Sierra Leone: An Ex Post Facto Study. Budapest International Research and Critics Institute-Journal (BIRCI-Journal). P. 3185-3196.

Ménard, C. (2008). A New Institutional Approach to Organization. In Handbook of New Institutional Economics (pp. 281-318). Springer, Berlin, Heidelberg.

Meyrina, R. S. A. (2017). Implementasi Peningkatan Kinerja Melalui Merit Sistem Guna Melaksanakan Undang-Undang Aparatur Sipil Negara No. 5 Tahun 2014 Di Kementerian Hukum Dan Ham . Jurnal Ilmiah Kebijakan Hukum, 10(2), 175-186.

Nasir, N. (2019). Implementasi Kebijakan Seleksi Terbuka Dalam Pengisian Jabatan Pimpinan Tinggi Pratama Di Lingkup Pemerintahan Kabupaten Toraja Utara. Kolaborasi: Jurnal Administrasi Publik, 5(2), 154-174.

Noors, A. I. A. (2019). Analisis Pelaksanaan Seleksi Terbuka bagi Pengisian Jabatan Pimpinan Tinggi di Indonesia. Konferensi Nasional Ilmu Administrasi, 3(1).

Notoatmodjo, S. (1992). Pengembangan Sumber Daya Manusia. Jakarta: Rineka Cipta.

Pasiak, P. (2020). Pengembangan Karier Aparatur Sipil Negara (ASN) Berdasarkan Sistem Merit Menurut Undang-Undang Nomor 5 Tahun 2014 Tentang Aparatur Sipil Negara Pada Pemerintah Kota Bitung. LEX ADMINISTRATUM, 8(2).

Pattipawae, D. R. (2011). Penerapan Nilai-Nilai Dasar Budaya Kerja Dan Prinsip-Prinsip Organisasi Budaya Kerja Pemerintah Dengan Baik Dan Benar. Sasi, 17(3), 31-44.

Prasodjo, E. (2014). Undang-Undang Aparatur Sipil Negara. Civil Service Journal, 8(1).

Prasojo, E., \& Rudita, L. (2014). Undang-Undang Aparatur Sipil Negara: Membangun Profesionalisme Aparatur Sipil Negara. Jurnal Kebijakan dan Manajemen PNS, 8(1), 13-29. 
Prasojo, E., \& Rudita, L. (2014). Undang-Undang Aparatur Sipil Negara: Merubah DNA Birokrasi. Jurnal Ilmu Pemerintahan: Reformasi Birokrasi, MIPI, Edisi, 45.

Simamora, H. (1995). Manajemen Sumber Daya Manusia, 1st Edition. Yogyakarta, STIE YKPN Publisher.

Sinambela, L. P. (2021). Manajemen Sumber Daya Manusia: Membangun Tim Kerja Yang Solid Untuk Meningkatkan Kinerja. Bumi Aksara.

Singarimbun, M., \& Effendi, S. (2019). Metode Penelitian Survai. Ministry of Health Research and Development

Steers, R. M. (2003). Organization Effectiveness, A Behavioral View, Good Year Publishing Company, translated by Magdalena Jamin. Jakarta: Erlangga

Sugiyono. (2011). Metode Penelitian Kuantitatif, Kualitatif, dan R\&D. Bandung: Alfabeta.

Suradinata, E. (1996). Manajemen Sumber Daya Manusia. Bandung: Ramadhan.

Syahril, S. (2018). Pengaruh Seleksi Dan Kompetensi Terhadap Prestasi Kerja Karyawan Pada PT. Umega Sembilan Berlian. Jurnal Ekonomi dan Bisnis Dharma Andalas, 20(2), 348.

Syardiansah, et al. (2020). The Effect of Job Satisfaction and Organizational Culture on Employee Performance of the Royal Hotel in East Aceh District. Budapest International Research and Critics Institute-Journal (BIRCI-Journal). P. 849-857.

Wibowo. (2009). Manajemen Kinerja, 2nd Edtion. Jakarta : Rajawali Press.

Widjaja, T. A. (1995). Akuntansi Sumber Daya Manusia. Jakarta: Rineka Cipta.

Zainun, B. H. (2000). Manajemen Sumber Daya Manusia, Jakarta: Gunung Agung. 